\title{
Use of Media as an Indicator of Modern Trend of Female Pakistani Dakwah Groups
}

\author{
SAIMA ESMA ${ }^{1}$
}

\begin{abstract}
This study looked into the organized use of modern media technology by female Dakwah (Islamic propagation) groups in Pakistan as an indicator of modern trends prevalent among such groups. The two groups selected for this study were the Women's Wing Jamaa'at e Islami and Al-Huda International Welfare Foundation. The time period of data is from June 2012 to December 2013. As a predominantly inductive research, this study shows that the ideological ground prepared by Women's Wing Jama'at-e-Islami in Pakistani Muslim women was utilized by Al-Huda with a selective approach and a progressive use of modern media. It argues that a proactive discourse on status of women in Islam and female religious scholarship can be anticipated by such groups for being independent and pluralist. The study suggests a synergizing of likeminded groups towards women's empowerment under the rubrics of Islam.
\end{abstract}

Keywords: Dakwah, Islamic feminism, Islamic propagation, modern media

In a world which is defining the meaning of literacy anew in terms of computer literacy, the application of latest information and communication technology has become a norm. The application and usage of modern ICT is a signifier of progress and modernity. Getting the message across effectively is the main purpose around which the whole activity of media revolves, and we find the same at the heart of all prophetic activity as a messenger of God to the mankind. Especially Muslims believe Da 'wah (dissemination of Islam's message) obligatory for every Muslim as a religious duty which is not gender specific. According to Holy Qur'an (9:71): "and the believers, men and women, are protecting friends one of another; they enjoin the right and forbid the wrong" (Pickthall 2001; Shandler 2009). In the early times of Islam, women equally contributed in calling others for Islam despite anticipating dire consequences.

The explosion of advanced media technology in the latter half of the twentieth century gave rise to an acute digital divide among North and South of the globe. As the South largely comprised of the Muslim World which was underdeveloped and colonized, scholars like Mustafa Masmudi (1978) and Hamid Mowlana (1985) showed their grave concerns over the situation. The gap widened in the case of traditional religious circles in Muslim societies who generally tended to resist new media for its Western roots. While the socio-historical situations were in dire need of adopting newer forms of communication strategies for religious propagation, Muslim preachers and popular leaders continued to eschew modern trends.

At the same time, there was a gender based divide regarding dakwah within Muslim societies, especially the organized and institutionalized dakwah became a predominantly male territory. Women were generally perceived as exempted from this religious duty by virtue of

\footnotetext{
${ }_{1}$ Saima Esma, Ph.D. candidate at Institute of Communications Studies, University of Punjab, 54890 LAHORE, Pakistan, email: saima@theyouthimpact.org.
} 
their natural and biological obligations of motherhood and wifehood. A gradually increasing general trend of non-acceptance of female religious scholarship to speak for religion of Islam itself (An-Na'im 1995) in Muslim societies with time also seems to contribute in the waning of female dakwah activism, as the two areas grow in concurrence.

In Subcontinent, it was as late as the middle of $20^{\text {th }}$ century that the need for an organized and educated form of female dakwah was felt by the religious circles. After the creation of Pakistan, Jamaa't e Islami's Women Wing commenced its organized dakwah activities among the women of educated class and make difference in their lives regarding their common perceptions and practices of religion. Following the footsteps, some other female groups emerged i-e female wings of Tanzeem e Islami, Jamaat u-dda'wah and Tehreek Minhaj ul Qur'an were the prominent ones. A new wave of organized female dakwah started with the emergence of Al-Huda some twenty years ago, that altered the existing female dakwah scenario in Pakistan to a great deal, gradually giving rise to the emergence of few more similar groups. A major distinction of Al-Huda was the aggressive use of selected forms of media prevalent at that time for its purpose including Television, VCR, Audio cassette players, FM radio followed very soon by computers and internet.

As the two selected groups claim to be non sectarian with members from heterogeneous following, they refer to original sources of Quran and Sunnah for guidelines. In contemporary academics this can be termed as an Islamist's way who 'attempts to propagate and purify Islam and gets actively involved in organizations which aim to transform society along Islamic lines' (Maumoon 1999). The rationale for this study comes from the same definition; there is a need to know the realization of such groups for an appropriate use of media and its reflection in their policies and practices in the way of their cherished mission of transforming society along Islamic lines. The researcher had been participating in the assorted sessions of both the groups for last many years. Thus the impetus of this study also came from the personal intrigue as what are the factors that let Al-Huda flourish on the basis of aggressive use of media tools, a practice considered religiously unsuitable for Muslim women dakwah workers of established female religious organizations in Pakistan like Women's Wing Jama'at e Islami (denoted by the Wing onwards). Also to explore and analyze the reasons of such lag behind on the part of this older institution was aimed. Thus the fundamental questions posed in this regard were:

- What is the level of acceptability for the use of modern media technology among Female Religious Groups in Pakistan, and what are the future prospects of the media usage by them?

- What is the extent of challenges they are facing posed by traditional nature of their society, male oriented religious circles and the mindsets of their own members?

\section{Literature Review}

Though still in developmental phase, Religious Communication is a field of ongoing research in the broad arena of investigation under Communication Studies. Stout (2013) regards it an understudied area, while Hoover (2013) has explored how mass media relates to contemporary religious and spiritual life. The issue of acceptability for modern media among religious groups is encountered across faiths. This variable has been qualitatively studied by (Shandler 2009) and (Campbell 2011). The advent of telephone generated a debate between Amish and Old Order Mennonites at the turn of twentieth century in Pennsylvania being favored as 'a divine service' and opposed as 'the devil's wires' (Shandler 2009). Campbell holds that while the Internet is readily utilized by many Orthodox Jewish groups, it is still viewed by some with suspicion (Campbell 2011). He finds religious people not anti-technology rather constrained by 
a number of social and faith based factors which inform and guide their responses to the possibilities and challenges offered by new forms of media (Shandler 2009).

Khomeini mobilized public for an unarmed resistance and non cooperation movement through his audio taped speeches (Mowlana 1979). Charles Hirschkind while admitting the efficacy and inspirational power of cassette sermons among the Muslim publics of Middle East apprehends those as the source of religious extremism in Muslim publics all over the globe. However he considers the tapes as part of a 'complex ethical and political project' to their listeners which cannot be simply termed as militancy (Hirschkind 2006). He perceives this as a threat to 'much espoused goal of promoting democracy in the Middle East'. However the recent Arab Spring refutes his notion whereby the public rallied huge street protests against their respective dictatorial regimes (Lotan et al. 2011). Besides this, he also argues that these sermons have led the Muslim publics to an ethical self improvement and polishing their sense of a pious living. Wu et al. (2011) found similarities with Two-Step flow in the model of diffusion of information in the case of Twitter.

The political interpretation of Islam by Jama'at e Islami's founder Sayyed Maududi invited strong criticism by traditional Muslim clergy along with the secularist circles. Along with pursuing its political agenda, Jama'at also led the Afghan Jihad shouldering Pakistan Army (Muehlenbeck 2012). While criticizing the 'secular extremism' masquerading in liberal thought, John Esposito includes JI among those Islamist forces who do not subscribe to violence and participate in electoral process (Esposito 2000). However the detailed studies conducted on Jama'at's working and influence in Pakistan including the work of Vali Reza Nasr (Nasr 1994; 1996) are devoid of discussion on its female wing's working and influence separately. Referring to the JI women, Amna Jamal (2005) argues that Islamist movements in Muslim societies are also the catalysts of modernization, rather than simply its interlocutors. Husnul Amin's study of JI in the perspective of 'dissenting voices of defected and seceded activists' (Amin 2010)and the historical and generational factors he refers to bare a critical importance towards shaping the future course of action for JI in Pakistan. Referring to Sadaf Ahmad (2009), Khanum Shaikh (2010) holds that an approach to the production of religious knowledge in harmony with the general religio-nationalist discourse of the country is one of the reasons of Al-Huda's success. In her own study on Al-Huda, Shaikh (2011) finds Farhat and her organization an equal cause of concern for the established male religious circles in Pakistan and self-identified progressive Muslims in Canada and examines 'how reformist women's agency becomes visible vis-à-vis differently situated hegemonies of knowledge and power in different national contexts'. Although Mushtaq (2010) has explored the socio psychological reasons of Al-Huda's popularity, she has also put forth a feminist critique on its impact. However unlike Mumtaz Ahmad (2010), she does not bring into consideration the sophisticated use of electronic media being among the primary reason of Hashmi's success. Nevertheless, Mushtaq's analysis of Hashmi's venture with a feminist critical perspective overlaps with this study, with a difference of this researcher's particular focus on the resistance faced by Hashmi for being media user.

This study is guided by the academic debates on the role and status of Muslim women by researchers of feminism, especially Islamic feminism. Since the objective of this study is to explore the trends of modernism in subject groups, the use of contemporary media with their peculiarities as presented in Medium Theory by Marshal McLuhan (1964) also provides a suitable framework for our discussion. 'Media, apart from whatever content is transmitted, impact individuals and society' (Medium Theory). The Uses and Gratification Approach (Katz et al. 1973) also provides us a ground to discuss the need-based uses of mass media. 


\section{Methodology}

The intended findings of this research were realized through triangulation of methods and measures with sufficient ethnographic readings, primary and secondary data gathering techniques, in-depth interviews and personal communication with the students and workers in these organizations. A survey questionnaire was designed in order to know the current level and future planning of use of MMT by these groups, and to assess the mindsets of their members. The universe or the target population for this research was the female religious groups in Pakistan while the accessible population was the leaders and followers of two selected groups from the female Da'wah scene of Pakistan. The quantitative data has been collected through survey questionnaire for individuals holding key positions at central and top level of these groups with a purposive sample. The sample size was different for each group owing to the difference in their organizational structure and magnitude of activities. In total, 68 office bearers were contacted. The achieved response rate was $65 \%$. The survey instrument designed carried more than $80 \%$ questions providing quantitative data for different variables which has been included in the report in the form of tables. Convenience sampling method was used for individualistic and informal data gathering through personal communication. Personal interviews were conducted with a select group of target respondents from both groups under study. Heads of the organizations, In charge Human Resource sections, In Charge Media Cells, Heads of Organization Bureaus, and Heads of Training and Development of both groups were interviewed. Eminent personalities among religious scholars who could represent large sects of Islamic scholarship in Pakistan were also interviewed. A considerable chunk of observation and analysis about the subject groups of this study was based on ethnographic readings of the writer.

\section{Results and Discussion}

Contrary to the Muslim Brotherhood's movement in Arab countries and the Iranian revolution where verbal discourse was made the foremost appeal, JI's literature in printed form has been one of its major strengths both for the purpose of dakwah and the education of new associates. This extensive ideological literature is mainly written by Sayyed A. A. Maududi and his ideological allies. Maududi's Quranic exegesis and different books written by him on Hadith, Seerah and Islamic ideology constitute the course studying which is a prerequisite for an associate to proceed to the next level of the organization's trust as well as responsibility. JI's official publishing house, along with a few other privately associated ones, keeps this literature readily available on demand at affordable and sometimes subsidized prices. Since the advent of the internet, JI's literature has been uploaded on different websites slowly and gradually mostly by individuals rather than on official grounds. Although there are a number of valuable books and pamphlets available in soft form but that is negligible compared to the total mass of this treasure in written form.

The Wing's official website was launched in 2003 which mirrors its multifaceted activity and the party's view point on emerging scenarios. Keeping in view the heterogeneity of its audience, the website has a humble standing compared with that of Al-Huda. To say the least, the introductory accounts of the organization's top leadership that website bears are monochromatic and bland, unable to generate an intrigue for these fine personas. The Wing started its activity on social media in February 2012 including Facebook, Twitter and YouTube along with the SMS service for information. Official working of the Wing is being computerized slowly and gradually since 2010. A production house is in working since 2007 with fairly sophisticated equipment, having audio and video recordings of Quranic lectures, few 
documentaries and cartoon based learning programs for children on its credit. A central SMS intimation service is active to provide prompt updates on the activities of the Wing.

Al-Huda's growth owes to the unprecedented use of audio cassette technology in the early years of its launching in Rawalpindi. Taking an informal humble start in early 90s, Al-Huda was a domestic venture of Farhat Hashmi, a graduate of International Islamic University Islamabad with a doctorate degree in Hadith Sciences from Glasgow University Scotland. By 1999, the cassettes of Hashmi's lectures were a main source of Al-Huda's introduction to multiple circles of female socialites especially in the twin cities. Digital recording with professional editing facility and a mass production of recorded lectures with AV technology gave a boost to the activity of Al-Huda in Karachi. Farhat gives a straightforward credit to the followers for extending generous help to the cause of Al-Huda (Farhat 2013). Website was launched in 2001. In the media coordinator's view, the work expanded manifolds with the use of proper media technology and from one computer and printer the Institute grew to its present magnitude wherein all managerial operations are computerized and three websites are working. An impressive collection of audio and video Quranic explanation by Hashmi and few others, both topical and sequential, are available in English along with Urdu on the website. The mass mail list on the website having 90 thousand to 100 thousand clicks a day shows large amount of visits. An IVR (Interactive Voice Response) service is also imparting knowledge to the students of religion on a variety of topics. Very well aware and rather conscious of their elitecentered fame, women at Al-Huda are now eager to expand their courses to the villages. However courses have been devised for rural populations with a minimum matriculation level of education, which is hard to find in the rural areas of a country with a very low literacy rate. The official use of Facebook was resisted by the Central Shura of Women's Wing JI till 2011 owing to the protest by its members on blasphemous material promoted on the network. Finally the page was opened on December 2nd, 2012. Al-Huda ventured on Facebook in 2013.

\section{Is There More To Come?}

Expounding the ideological standing of his party, Maududi enunciates a plan to implement that ideology in all walks of life including the art and literature (Maududi 2013). While the Women Wing carried on its well designed activities in creating quality literature for women and children through its periodicals and publishing houses, the domain of art remained untouched and unattended throughout the course of its history. The proclivity to bracket the trend of cinema going with a non serious, rather perverted class among the religious public in Pakistan remained so as the local film industry supported this trend by persistently presenting highly distasteful content. Despite proving as highly effective medium to approach masses, and a recent powerful example of its reformist use by revolutionary quarters in Iran, the data on behalf of both the groups shows that filmmaking is still a no go area among the female religious groups in Pakistan (Table 1). TV drama is another established source of cultural and social change. However, both the groups earned an equally negligible amount of opinion (8\%) for any prospects of utilizing the potential of TV drama in order to pursue the organizational objectives. Same is true for other genres of film, stage drama and fine arts. However, Geet (melody) has a better rating $(14 \%)$ at JIWW compared with a $0 \%$ response at AIWF: 
Table 1: Prospects of Using Different Genres of Media Content in Future

\begin{tabular}{lllll} 
& \multicolumn{2}{c}{ Genre } & JIWW & \multicolumn{2}{c}{ AIWF } \\
\hline Film & $\mathrm{N}$ & $\%$ & $\mathrm{~N}$ & $\%$ \\
Documentary & 1 & 2 & 1 & 8 \\
TV drama & 26 & 51 & 6 & 50 \\
Stage drama & 4 & 8 & 1 & 8 \\
Fine art & 0 & 0 & 1 & 8 \\
Melody & 4 & 8 & 0 & 0 \\
None & 7 & 14 & 0 & 0 \\
Totals & 9 & 18 & 3 & 26 \\
$\mathrm{n}_{1=35} \mathrm{n}_{2=9}$ & 51 & & 12 & \\
\hline
\end{tabular}

\section{Melodies}

Melodies have always been a favorite and powerful way of arousing motivation among purpose driven groups, in the armies, and for revolutions and popular movements. In the case of Jama'at e Islami, there had been a total neglect of this technique as a means of popular appeal for JI's agenda during election campaigns or public drives. The only time this captured the focus of Party's leadership was the years of Afghan and Kashmir Jihad starting from 1977 to the early 90 s, when an aggressive use of melodies was made through a special media department of Sama o basar, largely due to the involvement of Party's youth wing. However, even in those times, the use of melody as a means of public appeal during the campaign of 1991 general elections, remained an unpalatable idea that caused the Ameer, Qazi Hussain Ahmad make a retreat on his election's policy. On the other hand, a good use of this technique to get a mass appeal has been seen on the behalf of Islamic revivalist movements in other parts of the world during last ten years especially in the mass movements of Arab spring. The popular singers of national fame composed their melodies in the favor of Muslim Brotherhood's government to repudiate the liberalist propaganda against Ikhwan for being anti art and culture (Aziz 2012). Documentary film is the only genre that is included in the future planning of these groups. A considerable percentage of respondents, $26 \%$ and $33 \%$ in both the groups do not find any of the mentioned genres of media content included in their future planners (Table 1).

\section{Media Houses}

On the question of any plans for the Group's own TV or FM channel, 86\% of those answering positively at Al-Huda see it materializing in next three to five years, while a majority of the respondents $(57 \%)$ at the Wing do not see any such plan on organization's behalf, followed by $35 \%$ and $37 \%$ who do not watch TV and FM channels respectively, being opened ever (Table 2). In the qualitative response to the questions of future planning on the use of media, few of the respondents were suggestive of utilizing the full space given by Shariah in order to play an effective role on this front. 
Vol. 8: (Dec.) 2015

Table 2: Any Future Plans for Opening TV or FM Radio Channel

\begin{tabular}{|lllll|}
\hline Plans & $\underline{\mathrm{IIWW}}$ & & \multicolumn{1}{l|}{ AIWF } \\
Yes & $\mathrm{N}$ & $\%$ & $\mathrm{~N}$ & $\%$ \\
No & 10 & 29 & 7 & 78 \\
Don't know & 20 & 57 & 0 & 0 \\
\hline $\mathrm{n}_{1}=35 \mathrm{n}_{2}=9$ & 5 & 14 & 2 & 22 \\
\hline
\end{tabular}

\section{The Most Preferred Methods}

Along with the classes (67\%), largely media based methods especially audio methods top the list of the most preferred methods of dakwah and tarbiyyah by the organization at Al-Huda. At JIWW, the preferred methods comprise largely of non-media methods with a major share of dars (the conventional way of Quranic explanation session with an informal audience usually on weekly basis) and ijtima (includes training programs, workshops, and study circles) by $72 \%$ respondents as the most preferred and $42 \%$ as the second most preferred method. As the most preferred method next to dars, the share of literature is the highest (24\%), while the "contacts" method is at a considerable level both as foremost and second preferred method ( $21 \%$ each) (Table 3).

Table 3: Preferred Methods of Dakwah and Tarbiyah Adopted by the Organization

\begin{tabular}{|c|c|c|c|c|c|c|c|c|}
\hline \multirow{3}{*}{ Type of method } & \multicolumn{4}{|c|}{ 凹WW } & \multicolumn{4}{|c|}{$\underline{\mathrm{AIWF}}$} \\
\hline & \multicolumn{2}{|c|}{ Ist PM } & \multicolumn{2}{|c|}{$\underline{2^{\text {nd }}} \mathrm{PM}$} & \multicolumn{2}{|c|}{ Ist PM } & \multicolumn{2}{|c|}{$\underline{2}^{\text {nd }} P M$} \\
\hline & $\mathrm{N}$ & $\%$ & $\mathrm{~N}$ & $\%$ & $\mathrm{~N}$ & $\%$ & $\mathrm{~N}$ & $\%$ \\
\hline Live classes, Dars, Ijtima' & 24 & 72 & 14 & 42 & 6 & 67 & 1 & 11 \\
\hline Audio recordings and other media based methods & 0 & 0 & 2 & 6 & 3 & 33 & 7 & 78 \\
\hline Contacts & 7 & 22 & 7 & 22 & 0 & 0 & 0 & 0 \\
\hline Literature/Publications & 1 & 3 & 9 & 24 & 0 & 0 & 0 & 0 \\
\hline Other* & 1 & 3 & 1 & 7 & 0 & 0 & 1 & 11 \\
\hline Totals & 33 & & 33 & & 9 & & 9 & \\
\hline
\end{tabular}

\section{Catering to the Emerging Needs}

The combination of authentic traditional Islamic scholarship with a prestigious degree on religious knowledge from a renowned foreign university not only accredited her as an authentic source on religion, but also enabled her to sense the thirst of religious knowledge in educated class which had drifted away from religion owing to a modern life style and foreign cultural influences. Her way of teaching Quran was such that women could relate to what she said. Hashmi's Tajweed classes served as a lure for ladies. A Uses and Gratification approach revolves around finding ways to satiate the needs felt by individuals, through different mass media. AlHuda's cassettes catered well for two major needs of common women; One, a thirst for pure knowledge of Quran and Hadith, and two, the longing for learning the correct recitation of Qur'anic text. This researcher had a chance to see some elderly women trying to utter Arabic words in correct pronunciation with a lot of difficulty in spite of their hard dialectal accents. Secondly, it was an appropriate mix of status, education and modern media in the form of AlHuda that made the religious knowledge a popular appeal for a commoner. Participation in Al- 
Huda became a source of multidimensional fulfilment. It provided socially recognized symbolic capital to those who were desirous of improving their worldly status as well as to those who were already privileged (Mushtaq 2010), Women might join Al Huda classes because of the boredom, lack of personal fulfilment or elitist concerns that some observers ascribe to them (Hyat 2001; Ali 2003; Matri 2003). The researcher attended a live video conference session of Hashmi simultaneously addressing her students in England and Islamabad. Sitting at a time with foreign students is an enriching experience. It imparts a feeling of minimizing distances between the developed world and ours, thus experiencing a sense of being part of the global community of believers.

\section{Religious Activism Facing Traditional Thought}

At the Wing, The question on importance of media earned $71 \%$ of the opinion as very important and $26 \%$ as fairly important while $3 \%$ of the respondents think that media is not so important (Table 12). The culturally and religiously suitable media for women are almost the same with print and social media on the top. Electronic media and video are not much preferred, while for $11 \%$ and $13 \%$ of the respondents, non media ways are better for women (Table 4 ).

Table 4: Importance of Media in Achieving Objectives

\begin{tabular}{|lllll|}
\hline Degree & JIWW & AIWF \\
& $\mathrm{N}$ & $\%$ & $\mathrm{~N}$ & $\%$ \\
Very important & 25 & 71 & 7 & 88 \\
Fairly important & 9 & 26 & 1 & 12 \\
Less important & 0 & 0 & 0 & 0 \\
Not so important & 1 & 3 & 0 & 0 \\
Totals & 35 & & 8 & \\
\hline $\mathrm{n}_{1=35 \mathrm{n}_{2}=9}$ & & \\
\hline
\end{tabular}

Table 5: Cultural and Religious Suitability of a Medium for Women

\begin{tabular}{|c|c|c|c|c|c|c|c|c|}
\hline \multirow[t]{4}{*}{ Medium } & \multicolumn{4}{|c|}{ JIWW } & \multicolumn{4}{|c|}{ AIWF } \\
\hline & \multirow{2}{*}{\multicolumn{2}{|c|}{$\begin{array}{l}\text { Culturally } \\
\text { Suitable }\end{array}$}} & \multirow{2}{*}{\multicolumn{2}{|c|}{$\begin{array}{l}\text { Religiously } \\
\text { suitable }\end{array}$}} & \multirow{2}{*}{\multicolumn{2}{|c|}{$\begin{array}{l}\text { Culturally } \\
\text { suitable }\end{array}$}} & \multirow{2}{*}{\multicolumn{2}{|c|}{$\begin{array}{l}\text { Religiously } \\
\text { Suitable }\end{array}$}} \\
\hline & & & & & & & & \\
\hline & $\mathrm{N}$ & $\%$ & $\mathrm{~N}$ & $\%$ & $\mathrm{~N}$ & $\%$ & $\mathrm{~N}$ & $\%$ \\
\hline Print & 22 & 29 & 25 & 36 & 4 & 21 & 6 & 25 \\
\hline Electronic & 19 & 25 & 17 & 24 & 8 & 42 & 11 & 46 \\
\hline Social & 25 & 33 & 20 & 29 & 3 & 16 & 4 & 17 \\
\hline Others* & 10 & 13 & 8 & 11 & 4 & 21 & 3 & 13 \\
\hline Totals & 76 & & 70 & & 19 & & 24 & \\
\hline
\end{tabular}

The major chunk of respondents at both groups has not differentiated between the culturally suitable means of communication and the religiously suitable ones (Table 5).Although a majority of respondents (86\%) at the Wing believe that there are no reasons for women not to appear on television and radio, the split of this negative answer is more of a qualitative nature. The 34\% response largely conditions women's media appearance with hijab, or with abiding by limitations imposed by Shariah, while the $9 \%$ consists of showing reservations and 
apprehensions about appearing on media at all. In case the Wing starts its own electronic media channel, the said mindset might prove to be a major hurdle in the course of its success, as the ideological clarity, knowledge, eloquence and articulation of thoughts which are considered to be the criteria for presenting on media are likely to be compromised with overemphasizing the up keep of ideal limits of hijab, keeping in view organization's extreme stance on the issue.

Stemming from the same ideological alma mater, Farhat had all those strengths that Jama'at e Islami equips its followers with for becoming effective change agents (Mushtaq 2010). However, it was not only the JI's-pattern-minus-political-agenda that worked; Hashmi bolstered and boosted it with a very unique rather unlikely but vital ingredient. In the capacity of being a woman, it was a male dominated society to the core that she was going to work in. She emancipated herself from the cultural frames of a female dakwah worker. In doing so she drew her inspiration from the early women of Islam in the Prophet's time. She persistently validated her independent struggle through her constant adherence to the path that she carefully chose for herself. It was her belief in herself combined with good managerial skills and an effective use of mass media that today not only around 10 thousand (an estimated figure) females but nearly two thousand male students are also benefitting from Al-Huda's courses. By and large, the same mindset is reflected in her followers. Women at Al-Huda believe in the dynamic and multidimensional role of early women of Islamic history and look forward to reviving the same in contemporary Muslim societies. The response by Al-Huda's members to the question on the importance of media for achieving objectives (Table 4) is unanimous on the positive side with none for 'less important' or 'not so important' which is in line with their practice.

\section{In the Crosshairs}

Hashmi never endorsed or aligned herself with the Islamic feminist tradition by any means; neither had she ever tried to claim the right of feminist interpretations of the sacred texts or in the words of Cook (2002, cited by Jawad (2009): "production of official Islamic knowledge". Coming from a hard core religious background, and must have been aware of the detestation that religious oriented circles-across genders of course-pose towards feminist notions, this might be a tactical move that helped pave her way as a female religious scholar intelligently eschewing formulized controversies. In spite of that, Al-Huda has been under severe criticism from traditional religious circles which Hashmi denied to have hampered her pace in any way (Farhat Hashmi 2013). A senior alim at Jamia Ashrafia Lahore, a traditional religious seminary of Deobandi following, expressed his grave concerns over Hashmi's thoughts and methodology rendering it a mockery of Din (Mufti Shahid Ubaid 2013). He did not approve of Hashmi's appearance on TV even with a covered face and making her voice heard by unrelated men. According to him, mother Ayesha's (RA) practice of teaching Quran to unrelated men was a 'situation of need' that cannot be validated today. "We are not at all against women's education; anything that a man can do, a woman can also do" says Mufti, adding: "If a mission is valid, the belief is correct, the activity is within the limits of Shariah prescribed by the Prophet (p.b.u.h), his companions and the four scholars of Islam, then it is not only valid but mandatory and cause of immense reward ... but only if!".

He does not believe in ijtihad (revisiting Quranic interpretations in the light of contemporary challenges) referring to renowned deobandi scholar Maulana Ashraf Ali Thanwi (1863-1943) by quoting him: "the doors for ijtihad are open but there is no one capable of entering" which is tantamount to closure of this door. To condition Islamic scholarship with the four Imams is akin to tunnel the teachings of Quran and Sunnah into the interpretations of established religious schools only. Thus accepting women's role and at the same time not letting anyone draw inferences from Quran and Sunnah afresh in the light of four scholarships is 
synonymous to a non acceptance of their role in dakwah in modern times. Keeping in view the fact that Hashmi's interpretations are not in conflict with the four Imams at large, and mostly in line with the ahl e Hadith school which has a vast following all over the world, such objections on her methodology seem unsubstantiated and reflect a misogynist mindset that cannot accept women being simultaneously righteous and independent in their thought and action.

The Barelvi school is even more perturbed on her predominantly Wahabi following which gives a straight forward negative ruling on praying on shrines and even the grave of Prophet (p.b.u.h). Her religious scholarship is also questioned by them for not having acquired a degree from a religious seminary. However they accept a woman's religious authority in giving fatwa provided she is qualified in dars e nizami and has learnt the art and science of giving religious decree by having spent time with religious scholars. They approve of women's role in dakwah for women but not their organized and planned media appearance even with veil or only through audio, whereby men are also among the audience, due to the potentiality of fitnah (Anas Raza 2013). However the objections of aforesaid traditional circles seem to be more based on sectarian division than gender-bias.

\section{The Rebels of Tradition}

Socially aware and non parochial religious figures have effectively used all forms of modern media to benefit from its multidimensional potential towards success in their venture (M. Ahmad 2010). Maududi adopted this strategy years back while launching his movement for 'establishment of the religious order' (Iqamat e deen) rendering the use of modern ways of mass communication (mostly print media at that time) an imperative for getting the JI's message across to educated class of subcontinent. Maududi received a warm patronage from Iqbal who invited him to migrate from Southern India (Hyderabad) to Northern India (Punjab) in 1936 to pursue the scholarly mission of proving Islam's ideological mantle on the face of modern Western philosophies (Sayyed Abul'Ala Maududi 1963). The stature of Maududi was well recognized by the father of the nation Muhammad Ali Jinnah soon after the birth of Pakistan, when he invited Maulana to deliver a series of lectures on radio Pakistan to provide guidelines for the future mapping of this 'land of the pure' founded on the ideology of faith (Saulat 1974). In the region highly resistant to new mass media technology, where ulama had denounced even the invention of the loud speaker, Sayyed Maududi started his venture with a vehement use of all available media, especially after creation of Pakistan. Publications of Jama'at were made available in all forms of print media e.g. books, pamphlets, periodicals, along with religious sermons by Maulana recorded on spools of magnetic tape, the initial form of tape recorder.

\section{Weak Heirs of a Bold Legacy}

Jamaa't 's women were the first ones working country wide (and remaining so till the advent of a small circle named Al-Huda in 1994 in Rawalpindi) who were carrying out dakwah activity in women's circles not only in an organized way but at the level of social connections and family ties. Many familiar concepts of Islam which seem to be quite accepted today by Pakistani female audience were introduced by Jamaa't's women in those early times. This activism in the form of dakwah inculcated an enormous sense of agency among the less privileged often suppressed and curtailed women in our traditional set up. Contrary to the liberal agenda of women's rights backed by the 'uncovered ladies' (beparda begmaat) of bureaucratic elite of the nascent country, an agency being sought through with a legitimacy of piety and conformity in a Muslim public was a much more serviceable route to gender empowerment. 


\section{The Share of Religious Orthodoxy}

Unlike the practice of Hashmi, the voice of woman heard by unrelated men is a taboo at the Wing. In the 1980s which is much before the birth of Al-Huda and the idea of audio cassettes striking Hashmi, an energetic and spirited member of JI from NWFP (KPK) took a courageous initiative of producing audio recordings of her Islamic motivational speeches only to abandon the activity soon on the orders from high quarters. There might be other issues related with the activity in a region that was to become highly volatile in coming years on the account of religious extremism, but the idea not being picked by other individuals or the leadership of the Wing afterwards as an effective tool of dakwah alludes to its aversive nature. Thus it was the death of a brilliant initiative there and then. Although a high graph of positive opinion on the question of importance of media was achieved at the Wing, the situation may not be the same ten years ago. The ideas of opening website and establishing a production house faced years' long process of deliberations and persuasions among high quarters before final approval (In charge production house, Personal Communication 2013).

\section{Media and Modernism}

Owing to the early times of mass media in the Subcontinent introducing picture houses, talkies and socializing or dancing clubs of Anglo-Indian elite, the general notion of an ascetic life was to keep from these indulgences. The same connotation was adopted by Maududi who presented a severe criticism on the influence of Western culture upon Muslim's living. The underutilized potential of modern media by the Wing is related with the same socio-psychological dimension. Modern media carries an association with 'Western' life style, the imperatives of which bear a tacit aversion among the people inspired by JI's ideology even today. A general perception of 'modern' in JI is akin to 'Western' owing to the scientific and technological developments being largely attributed to the West, which finally makes the 'modern' a legitimate subject of all the criticism by Maulana that was originally targeted to the West in those trying times for Muslims.

The early $20^{\text {th }}$ century was the time when Muslim ummah was undergoing enormous crises due to fall of the Khilafah and consequent balkanization of Muslim areas previously under the khilafah. Led by Kamalist Turkey, the whole Muslim world faced a powerful onslaught of Western culture in entirety i.e language, dressing, education, art and literature that was a cause of great concern for ulama and reformists of Hind. Now after 67 year of independence, with a not-so-independent political and social scenario, those have mostly mitigated into symbolic values of modernism, in comparison with the real threats of secularism engaging the focus of reformist movements around the Muslim world. The old binary divisions have camouflaged themselves into new signs and symbols. Narratives have been changed and reformulated to fit to the newer situations and so have the Islamic movements which are serving as change agents. In the words of Esposito (2000): "they establish modern political and social organizations and embrace advanced means to disseminate their message. Most function within civil society as social and political activists".

Also to some, the saturation of Western influence has precipitated into the rise of Islamism. Such movements have emerged as a response to westernization that had marginalized Islam as a means of organizing daily conduct and a complete way of life, in the words of Saba Mahmood (2011): "reducing it to merely an abstract system of belief that has no direct bearing on the practicalities of daily life". This view supports the argument in that the practicalities of life have changed. While there is found a clear hyper sensitivity for the outlook and the similitude of ensemble in the environment at the Wing, in afore mentioned context of changed realities, a more encompassing milieu may increase the organization's outreach to the 
diversified publics. Unlike Al-Huda's one woman show, the Wing's structure is hierarchical which is inherently not very change-friendly. That is one reason why it could not keep the pace with time on the crucial issue of using modern media as a female religious organization.

\section{The Spirit of Islamic Emancipation in the Face of Traditionalism}

The following highly inviting sentences from one of Maulana's early speeches to the congregation of women are quoted in the written history Rudad (1979) as under: "Women should not consider themselves as an addendum of their male kins; unto God they are responsible and accountable for their deeds the same way as men are ... women should organize to fulfill their every genuine requirement keeping within Shariah for which the violation of (Shariah's) boundaries is considered inevitable". Though he simply enunciated a principle of Quran in the earlier part of this quotation (everyone is responsible for his or her own deeds) but the discourse is highly emancipating in tone and in terms of outcomes as a directive for a female Islamist. This fundamental principle-turned-cliché seems unable to enrich the policy guidelines of the Wing today. Maulana's heretical tendency of carving his own path of Islamic scholarship in the highly traditional religious milieu of the subcontinent, and his perseverance in executing his idea of Islamic activism was highly progressive in nature. Expounding his position on the role of women in an Islamic government under JI's rule, Maulana guarantees an equal and equitable status of women that includes the highest levels of education, basic military training with the skills of using arms, first aid and driving vehicles in order to safeguard themselves and help men in the times of war if needed. He outright rejects the notion of keeping women like dolls under an Islamic rule.

The voluntary subservience; a spirit of piety or living in a comfort zone. A revision of sociology's model of subjectivity is one of the four distinctive features of a feminist sociology. While making generalization for women's subjectivity, Ritzer (1996) writes:

Their experience of role taking is complicated by their intense awareness that they must learn the expectations of another who by virtue of differences in power is alien; they do not experience themselves as purposive social actors who can chart their own course through life, although they may be constantly told that they can do so.

A de facto Independence, Women's Wing of Jamaat e Islami is the oldest and most organized religious group in Pakistan formally founded on March 1, 1948. The rationale given in the history of the Wing is as following: "... so that a woman, instead of consulting the Ameer $e$ Jamaat for discussing problems and issues related to the organizational duties, or having to contact the respective local set ups of male members, can directly contact the women's head who is in direct contact with the Ameer" (Ummezubair 1989). The concept of 'segregation' of genders is self-proclaiming of the authority of women and thus empowering in nature. Absurd though, it reminds one of the separatist feministstance of 'separation being initiated or maintained, at will, by women' (Frye 1997). The constitution of JI declares the organization of its female wing as similar and parallel to the male wing under the same Ameer. The strategies and policies of Women Wing have their legitimate standing as far as these are in line with the overall policy guidelines. However the factual situation may not be totally in line with the spirit of constitutional provisions. The researcher identified a general misconception on the constitutional authority of Women's Wing among its leaders. A term of tabe' nazm (the subservient structure) for the Wing is in vogue among them, while no reference could be generated as the origin of this term. This mindset can better be interpreted as the 'voluntary 
subservience' which minimizes the possibility of taking quality decisions on behalf of the leadership on the issues as crucial, delicate and polemical as the use of modern media. As a conclusion, these religious women have manifested a unique capability of coping with the seemingly contradictory ideas of religiosity and women's empowerment which is providing new dimension to study feminist issues. In fact, post modernism's belief in subjectivity and multiple truths along with its emphasis on knowledge being pluralistic that takes into account the social and cultural conditions, discourses and belief systems, is giving ample room for incorporation of such newer dimensions to the mainstream inquiries of feminism.

An aversion for secular feminist stances is understandable on these groups' behalf, especially when it has already receded in Muslim societies globally in the wake of Islamism in recent past, but the applicable and reasonable stances within Islamic feminism must be revisited by such groups of female dakwah who are educated, aware, articulate, pluralist and more encompassing in their religious thought. By virtue of their influence, leading and inspiring roles, commitment and substantiality of ideologies, efforts can be made by such groups to converge and synergize towards materializing the fairy tale goal of reinstating women's equitable status in the true spirit of Islamic message, not only in societies within Islamic geographical boundaries but embracing the non-believer publics as well. It is crucial for at least two reasons; (a) for reclaiming the dwindling trust of educated female youth of Muslim populations in Islam as best choice for being fair, unbiased and promising religion for women, (b) to compete the radically secular stances of Islamic feminism that reject any hopes of 'correct reading of Islamic texts' anticipating the unchallenged and controlling position of Muslim clerics.

In fact, about the Quranic interpretations regarding suppression of women, the basic issue seems not to be the gendered reading but its appropriateness to the contemporary challenges, which does not stipulate for a female authority- or a male one of course- for its formulation. The same argument is valid for a female Islamic scholar to prove her mettle as a religious authority. Thus a rather more valid concern arises from the current situation; why female authorities on religion cannot be developed within female Islamist circles; why there exists a tendency in Islamic activists to validate their practices on contemporary issues by the male circles of Islamic scholarship? This tendency underpins skepticism for the credibility of women in attainment of the critical balance of scholarship, virtuosity and wisdom conditioned to have an authoritative position in religion. Not being in line with the basic teachings of Quran, any such assumption is hard to justify. Keeping in view the common ideological ground and an Islamically inclusive approach, a need for synergizing of likeminded groups is found towards Muslim women's empowerment. By now, influence of Western thought seems to be a defining element for both sides of the schism; Islamic feminists for making Western paradigms as basic premise of their theorizing, and female religious activists for their reaction towards the same. Instead, a non-partisan approach envisaging the role of early women in Islam and the essence of Islamic principles, focusing on the real problems faced by Muslim women in respective locales with a spirit of reform may lead to solutions rather than confusions, and convergence in place of chaos. 


\section{References}

Ahmad, M. (ed.). 2010. Muslim Grassroots Leaders and Popular Preachers in South Asia (First ed.). Seattle: The National Bureau of Asian Research.

Ahmad, S. 2009. Transforming Faith: The Story of Al-Huda and Islamic Revivalism among Urban Pakistani Women. n.p.: Syracuse University Press.

Ali, S. 2003. Pakistani Women Socialites Embrace Islam. BBC News Online. 6 November.

Amin, H. 2010. From Islamism to Post-Islamism: A Study of a New Intellectual Discourse. Rotterdam: Erasmus University.

An-Na'im, A. A. 1995. Toward an Islamic hermeneutics for human rights. In Human Rights and Religious Values: An Uneasy Relationship.

Aziz, A. 2012. Akhbar e Ummat; mazeed kamiyabian aur sazishen. Tarjuman ul Qur'an. March.

Campbell, H. 2011. Religion and the Internet in the Israeli Orthodox context. Israel Affairs 17(3): 364-383.

Esposito, J. L. 2000. Political Islam and the West. JFQ.

Frye, M. (ed.). 1997. Some Reflections on Separatism and Power. New York: Routledge.

Hirschkind, C. 2006. The Ethical Soundscape: Cassette Sermons and Islamic Counterpublics.Columbia University Press.

Hoover, S. M. 2013. Religion in the Media Age. London: Routledge.

Hyat, K. 2001. Letter from Lahore: Hijab is New Fashion Statement among Wealthy. Gulf News. March.

Interview Sayyed Abul'Ala Maududi. 1963. Monthly Sayyarah. May, 35.

Jamal, A. 2005. feminist'selves' and feminism's' others': feminist representations of Jamaat-eIslami women in Pakistan. Feminist Review: 52-73.

Jawad, H. 2009. Islamic feminism: Leadership roles and public representation. Hawwa 7(1): 124.

Katz, E., Blumler, J. G., \& Gurevitch, M. 1973. Uses and gratifications research. The Public Opinion Quarterly 37(4): 509-523.

Lotan, G., Graeff, E., Ananny, M., Gaffney, D., Pearce, I., \& Boyd, D. 2011) The revolutions were tweeted: Information flows during the 2011 Tunisian and Egyptian revolutions. International Journal of Communication 5: 1375-1405.

Matri, S. 2003. The Opiate of the Elite. Newsline. December.

Maududi. 2013. Tehreek e Islami; ek tarekh ek dastan (2 ed.). Lahore: Manshurat.

Maumoon, D. 1999. Islamism and gender activism: Muslim women's quest for autonomy. Journal of Muslim Minority Affairs 19(2): 269-283. doi: 10.1080/13602009908716442

Medium Theory.). Overview Communication Theories Retrieved 7 December, 2013, from http://www.utwente.nl/cw/theorieenoverzicht/Levels\%20of\%20theories/macro/Culti vation\%20Theory.

Mowlana, H. 1979. Technology versus tradition: Communication in the Iranian revolution. Journal of Communication 29(3): 107-112.

Mowlana, H. 1985. International Flow of Information: A Global Report And Analysis. New York: United Nations Educational.

Muehlenbeck, P. (ed.). 2012. Religion and the Cold War: A Global Perspective. Vanderbilt University Press.

Mushtaq, F. 2010. A Controversial Role Model for Pakistani Women. South Asia Multidisciplinary Academic Journal 4.

Nasr, V. R. 1994. The Vanguard of Islamic Revolution: The Jamaat e Islami of Pakistan (1 ed.). USA: University of California Press. 
Nasr, V. R. 1996. Mawdudi and the Making of Islamic Revivalism. New York: Oxford University Press.

Pickthall, M. M. 2001. The Glorious Qur'an: The Arabic Text with a Translation in English. Ttq, Inc.

Ritzer, G. 1996. Sociological . (4 ed.). McGraw-Hill.

Rudad. 1979. Volume 6. Lahore: Press \& Publications Dept.

Saulat, S. 1974. Maulana Maududi ki Taqareer (Vol. 1). Lahore: Islamic Publications Limited.

Shaikh, K. 2010. Transforming Faith: The Story of Al-Huda and Islamic Revivalism Among Urban Pakistani Women (review). The Middle East Journal.64(2): 312-313.

Shaikh, K. 2011. Gender, Religious Agency, and the Subject of Al-Huda International. Meridians: Feminism, Race, Transnationalism.11(2), 62-86.

Shandler, J. 2009. Jews, God, and Videotape: Religion and Media in America. New York: NYU Press. Stout, D. A. 2013. Media and Religion: Foundations of an emerging field: Routledge.

Ummezubair. 1989. Tehreek e Islami Men Sho'ba-e-Khawateen (self, Trans. First ed.). Lahore: Idara Batool.

Wu, S., Tan, C., Kleinberg, J. M., \& Macy, M. W. 2011Does Bad News Go Away Faster? Paper presented at the ICWSM. 